\title{
Functional improvement in patients with idiopathic pulmonary fibrosis undergoing single lung transplantation*
}

\author{
Melhora funcional em portadores de fibrose pulmonar idiopática \\ submetidos a transplante pulmonar unilateral
}

\author{
Adalberto Sperb Rubin ${ }^{1,2}$, Douglas Zaione Nascimento' ${ }^{1}$, Letícia Sanchez ${ }^{1}$, \\ Guilherme Watte ${ }^{2}$, Arthur Rodrigo Ronconi Holand', \\ Derrick Alexandre Fassbind ${ }^{1}$, José Jesus Camargo ${ }^{1,2}$
}

\begin{abstract}
Objective: To evaluate the changes in lung function in the first year after single lung transplantation in patients with idiopathic pulmonary fibrosis (IPF). Methods: We retrospectively evaluated patients with IPF who underwent single lung transplantation between January of 2006 and December of 2012, reviewing the changes in the lung function occurring during the first year after the procedure. Results: Of the 218 patients undergoing lung transplantation during the study period, 79 (36.2\%) had IPF. Of those 79 patients, 24 (30\%) died, and $11(14 \%)$ did not undergo spirometry at the end of the first year. Of the 44 patients included in the study, 29 (66\%) were men. The mean age of the patients was 57 years. Before transplantation, mean FVC, $\mathrm{FEV}_{1}$, and $\mathrm{FEV}_{1} / \mathrm{FVC}$ ratio were $1.78 \mathrm{~L}$ (50\% of predicted), $1.48 \mathrm{~L}$ (52\% of predicted), and 83\%, respectively. In the first month after transplantation, there was a mean increase of $12 \%$ in FVC (400 mL) and FEV $(350 \mathrm{~mL})$. In the third month after transplantation, there were additional increases, of 5\% (170 mL) in FVC and 1\% (50 $\mathrm{mL})$ in $\mathrm{FEV}_{1}$. At the end of the first year, the functional improvement persisted, with a mean gain of $19 \%(620$ $\mathrm{mL}$ ) in FVC and 16\% (430 mL) in FEV. Conclusions: Single lung transplantation in IPF patients who survive for at least one year provides significant and progressive benefits in lung function during the first year. This procedure is an important therapeutic alternative in the management of IPF.
\end{abstract}

Keywords: Pulmonary fibrosis; Respiratory function tests; Lung transplantation.

\section{Introduction}

ldiopathic pulmonary fibrosis (IPF) is defined as a specific form of chronic, progressive fibrosing interstitial pneumonia that is fatal. This poor prognosis is always associated with deterioration of lung function, ${ }^{(1)}$ and estimated median survival after diagnosis is 2.8-4.8 years. ${ }^{(2-6)}$ Although IPF can remain stable indefinitely in some patients, it progresses to loss of lung function in the vast majority of cases. It has recently been found that the therapeutic strategy adopted worldwide, i.e., the use of corticosteroids and immunosuppressants, is possibly associated with increased mortality in patients with $1 P F .{ }^{(7)}$ In view of the inefficacy of currently available therapeutic measures and the rapid and inexorable progression of IPF, lung transplantation remains one of the few effective treatment options. ${ }^{(1,4,8,9)}$

The first single lung transplantation was performed at the University of Toronto in $1983^{(10,11)}$ in order to treat IPF, being successful and resulting in prolonged patient survival. In recent years, lung transplantation has been increasingly recommended for the management of IPF, and, in many centers, it is the standard of care for IPF. (12-15) Current data on lung transplantation for the treatment of IPF show that the procedure has a significant impact on patient survival, estimated $1-, 5-$, and $10-$ year survival rates being $74 \%$, $45 \%$, and $22 \%$, respectively. ${ }^{(12)}$

*Study carried out at the Pavilhão Pereira Filho, Santa Casa de Porto Alegre; and at the Universidade Federal de Ciências da Saúde de Porto Alegre, Porto Alegre, Brasil.

1. Pavilhão Pereira Filho, Santa Casa de Porto Alegre, Porto Alegre, Brasil.

2. Programa de Pós-Graduação em Pneumologia, Universidade Federal de Ciências da Saúde de Porto Alegre, Porto Alegre, Brasil. Correspondence to: Adalberto Sperb Rubin. Universidade Federal de Ciências da Saúde de Porto Alegre, Rua Sarmento Leite, 245, Centro, CEP 90050-170, Porto Alegre, RS, Brasil.

Tel.: 5551 3303-9000. E-mail: arubin@terra.com.br

Financial support: None.

Submitted: 20 March 2015. Accepted, after review: 22 June 2015. 
Few studies conducted in Brazil or any other country and including a significant number of patients have determined the beneficial impact of transplantation on lung function in patients with IPF. ${ }^{(14)}$ In addition to providing symptom relief and improving quality of life, stable or improved lung function is associated with reduced mortality in patients with IPF. ${ }^{(16)}$ The objective of the present study was to evaluate lung function in the first year after single lung transplantation in patients with IPF in order to show the real functional benefit of this therapeutic strategy.

\section{Methods}

We retrospectively reviewed the medical records of IPF patients undergoing lung transplantation at the Santa Casa de Misericórdia de Porto Alegre lung transplant center, in the city of Porto Alegre, Brazil, between January of 2006 and December of 2012. All of the patients in the sample underwent single lung transplantation, and 1-year survival was evaluated.

\section{Study sample and inclusion and exclusion criteria}

We included patients diagnosed with IPF in accordance with the latest American Thoracic Society, European Respiratory Society, Japanese Respiratory Society, and Latin American Thoracic Association consensus statement. ${ }^{(1)}$ The diagnostic criteria for IPF are as follows: a) exclusion of other known causes of interstitial lung disease, such as occupational or household exposure, connective tissue disease, and drug toxicity; b) a usual interstitial pneumonia pattern on HRCT in patients not undergoing surgical biopsy; and c) HRCT findings suggestive of IPF and a histopathological pattern consistent with the disease in patients undergoing surgical lung biopsy.

Radiological and histopathological criteria were in accordance with the recommendations of national and international guidelines, ${ }^{(1,2,17,18)}$ and in all of the patients included in the study the histopathological diagnosis was confirmed by analysis of the lung removed during transplantation. Radiological and histopathological analyses were performed in the thoracic radiology and diagnostic pathology departments of the Santa Casa de Misericórdia de Porto Alegre.
The patients who died before the first year of follow-up and those who were unable to undergo lung function assessment at the end of the first year after transplantation were excluded.

Before transplantation, patients had been receiving follow-up care from the clinical team at our lung transplant center, in accordance with then-current national and international guidelines for the treatment of IPF. ${ }^{(1,2)}$ All patients were enrolled in a pulmonary rehabilitation program for patients with fibrosing interstitial lung disease.

The lung that was to be removed was chosen on the basis of international guidelines for lung transplantation, ${ }^{(15)}$ the degree of lung impairment and lung size compatibility having previously been analyzed. As a rule, IPF patients at our center undergo single lung transplantation only.

\section{Pulmonary function testing}

All patients underwent pulmonary function testing before transplantation and during the first year of follow-up. All tests were performed at the same location, i.e., the Laboratório de Função Pulmonar of the Pavilhão Pereira Filho of the Santa Casa de Porto Alegre, being performed by a team of technicians trained in pulmonary function testing. All tests were performed with a MasterScreen 10S device (Viasys Health Care Global, Loma Linda, CA, USA), the results obtained in the first month, in the third month, and at the end of the first year after transplantation being analyzed. All pulmonary function tests were performed in accordance with the Brazilian Thoracic Association criteria and the American Thoracic Society criteria, ${ }^{(19,20)}$ and the predicted values were those derived for the Brazilian population. ${ }^{(21)}$

We analyzed the following spirometric parameters: FVC; $\mathrm{FEV}_{1}$; and the $\mathrm{FEV}_{1} / \mathrm{FVC}$ ratio.

\section{Statistical analysis}

Data were expressed as mean and standard deviation. Lung function variables were analyzed by the paired t-test. The level of significance was set at 5\% ( $\leq 0.05)$. The Wilcoxon test was used in order to determine the differences among pulmonary function test results.

\section{Results}

During the study period, 218 patients underwent lung transplantation at the Santa Casa 
de Porto Alegre. Of those, 79 (36.2\%) had IPF, all of whom underwent single lung transplantation. Of those 79 patients, 35 were excluded: 24 (30\%) died before the first year of follow-up; and 11 $(14 \%)$ did not undergo spirometry at the end of the first year after transplantation. Table 1 shows the demographic data of the study population $(\mathrm{N}=44)$. Of the sample as a whole, $29(66 \%)$ were male and 15 (34\%) were female. The mean age of the patients was 57 years. Mean FVC was $1.78 \mathrm{~L}$ (50\% of predicted), mean $\mathrm{FEV}_{1}$ was 1.48 $\mathrm{L}$ (52\% of predicted), and mean $\mathrm{FEV}_{1} / \mathrm{FVC}$ was $83 \%$, all of which are associated with restrictive lung disease, which is characteristic of pulmonary fibrosis.

Table 2 shows data regarding pre- and posttransplantation lung function in the 44 patients studied. In the first month after transplantation, there was a mean increase in FVC of more than $400 \mathrm{~mL}(12 \%)$ from baseline and a mean increase in FEV 1 of $350 \mathrm{~mL}(12 \%)$ from baseline. In the third month after transplantation, the functional improvement persisted, with an additional mean increase in FVC of $170 \mathrm{~mL}$ (5\%) from baseline and an additional mean increase in FEV of 50 $\mathrm{mL}(1 \%)$ from baseline. At the end of the first year, there was a mean increase in FVC of 620 $\mathrm{mL}(19 \%)$ from baseline and a mean increase in $\mathrm{FEV}_{1}$ of $430 \mathrm{~mL}$ (approximately 16\%) from baseline.

The graph in Figure 1 shows improved lung function (as assessed by FVC and FEV F $_{1}$ in the study sample during the first year after lung transplantation.

Of the 79 lung transplant recipients, 13 (16\%) died within 30 days after transplantation; 4 (5\%) died between the first and third months after transplantation; and 7 (9\%) died between the

Table 1 - Demographic characteristics of the 44 idiopathic pulmonary fibrosis patients undergoing single lung transplantation and included in the present study. ${ }^{\text {a }}$

\begin{tabular}{lc}
\hline \multicolumn{1}{c}{ Characteristic } & $(\mathrm{N}=44)$ \\
\hline Age, years $^{\mathrm{b}}$ & $57(32-69)$ \\
Male|Female, $\%$ & $66 \mid 34$ \\
$\mathrm{FEV}_{1}, \mathrm{~L}$ & $1.48 \pm 0.48$ \\
$\mathrm{FEV}_{1}, \%$ of predicted & $52 \pm 17$ \\
$\mathrm{FVC}, \mathrm{L}$ & $1.78 \pm 0.60$ \\
$\mathrm{FVC}, \%$ of predicted & $50 \pm 18$ \\
$\mathrm{FEV}_{1} / \mathrm{FVC}$ & $83 \pm 19$ \\
\hline
\end{tabular}

aValues expressed as mean \pm SD, except where otherwise

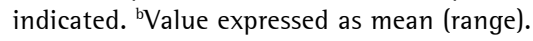

third month and the first year after transplantation (Figure 2), a total of 24 deaths having occurred $(30 \%)$.

\section{Discussion}

The data of the present study show that patients with IPF have a significant improvement in lung function during the first year after single lung transplantation. Improved lung function occurs as early as one month after the procedure, with a mean increase in FVC and FEV ${ }_{1}$ of $12 \%$ from baseline. The most important finding is that the functional improvement persists for 12 months following transplantation, with an additional mean increase of 19\% from baseline. Lung function improvement persisted despite the fact that patients underwent single lung transplantation rather than bilateral lung transplantation and the fact that the fibrotic process that had led to their being on the waiting list for lung transplantation persisted in the remaining lung. One limitation of the present study is that $14 \%$ of the patients who were eligible for inclusion did not undergo pulmonary function testing at the end of the first year after transplantation. Therefore, the study results refer exclusively to the lung transplant recipients who underwent all of the required spirometry tests. Among the IPF patients who underwent single lung transplantation at our center during the study period, 1-year survival was $70 \%$.

Given that IPF is a disease for which there is no pharmacological treatment whose efficacy in improving or even stabilizing lung function has been confirmed, ${ }^{(1)}$ the results of the present study underscore the need for lung transplantation in patients with IPF, transplantation being the only therapeutic measure that has any impact on lung function. ${ }^{(10)}$ Another reason why lung transplantation is the only viable treatment option for patients with advanced IPF is that disease severity and mortality rates in IPF patients waiting for lung transplantation are far superior to those in other lung transplant candidates. Hayden et al. ${ }^{(22)}$ reported six-month survival rates of $38 \%$ and $81 \%$, respectively, in patients with $\mathrm{PFF}$ and pulmonary emphysema undergoing lung transplantation.

Few studies have assessed functional improvement in IPF patients undergoing lung transplantation, many of which have shown incomplete data. ${ }^{(22-24)}$ Tomaszek et al. ${ }^{(25)}$ 
Table 2 - Lung function in the study sample $(\mathrm{N}=44)$ before and after single lung transplantation.

\begin{tabular}{|c|c|c|c|c|c|c|c|c|c|c|c|}
\hline \multirow[t]{2}{*}{ Variable } & \multirow{2}{*}{$\begin{array}{l}\text { Waiting } \\
\text { list }\end{array}$} & \multicolumn{3}{|c|}{ After LTx } & \multirow[t]{2}{*}{$\mathrm{p}^{\mathrm{a}}$} & \multirow[t]{2}{*}{$p^{b}$} & \multirow[t]{2}{*}{$\mathrm{p}^{\mathrm{c}}$} & \multirow[t]{2}{*}{$p^{d}$} & \multirow[t]{2}{*}{$p^{e}$} & \multirow[t]{2}{*}{$p^{f}$} & \multirow[t]{2}{*}{$p^{g}$} \\
\hline & & $\begin{array}{c}\text { 1st } \\
\text { month }\end{array}$ & $\begin{array}{c}\text { 3rd } \\
\text { month }\end{array}$ & $\begin{array}{c}1 \mathrm{st} \\
\text { year }\end{array}$ & & & & & & & \\
\hline $\mathrm{FEV}_{1}, \mathrm{~L}$ & $\begin{array}{l}1.48 \pm \\
0.48\end{array}$ & $\begin{array}{l}1.83 \pm \\
0.53\end{array}$ & $\begin{array}{l}1.87 \pm \\
0.55\end{array}$ & $\begin{array}{l}1.91 \pm \\
0.62\end{array}$ & $<0.001$ & $<0.001$ & $<0.001$ & 0.144 & 0.112 & 0.047 & 0.001 \\
\hline $\mathrm{FEV}_{1}, \%$ of predicted & $\begin{array}{l}52 \pm \\
17\end{array}$ & $\begin{array}{l}64 \pm \\
18\end{array}$ & $\begin{array}{l}65 \pm \\
19\end{array}$ & $\begin{array}{l}68 \pm \\
22\end{array}$ & $<0.001$ & $<0.001$ & $<0.001$ & 0.480 & 0.064 & 0.061 & 0.001 \\
\hline FVC, L & $\begin{array}{l}1.78 \pm \\
0.60\end{array}$ & $\begin{array}{l}2.22 \pm \\
0.60\end{array}$ & $\begin{array}{l}2.39 \pm \\
0.68\end{array}$ & $\begin{array}{l}2.40 \pm \\
0.65\end{array}$ & $<0.001$ & $<0.001$ & $<0.001$ & $<0.001$ & 0.005 & 0.084 & $<0.001$ \\
\hline FVC, $\%$ of predicted & $\begin{array}{l}50 \pm \\
18\end{array}$ & $\begin{array}{l}62 \pm \\
16\end{array}$ & $\begin{array}{l}67 \pm \\
18\end{array}$ & $\begin{array}{l}69 \pm \\
19\end{array}$ & $<0.001$ & $<0.001$ & $<0.001$ & 0.003 & 0.002 & 0.053 & $<0.001$ \\
\hline $\mathrm{FEV}_{1} / \mathrm{FVC}$ & $\begin{array}{l}83 \pm \\
19\end{array}$ & $\begin{array}{l}84 \pm \\
10 \\
\end{array}$ & $\begin{array}{l}80 \pm \\
12\end{array}$ & $\begin{array}{l}80 \pm \\
10\end{array}$ & 0.561 & 0.020 & 0.052 & 0.006 & 0.024 & 0.937 & 0.361 \\
\hline
\end{tabular}

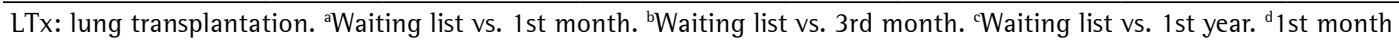
vs. 3 rd month. ${ }^{\mathrm{e}} 1$ st month vs. 1 st year. ${ }^{\mathrm{f}} 3 \mathrm{rd}$ month vs. 1 st year. ${ }^{9}$ The entire period.

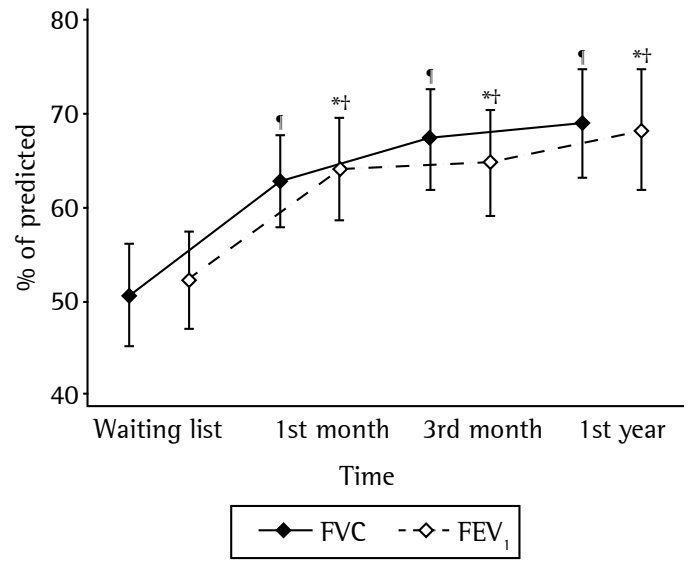

Figure 1 - Functional response to lung transplantation in the 44 patients who survived the one-year follow-up period. "All comparisons. *Waiting list vs. 1st month vs. 3 rd month vs. 1 st year. ${ }^{\dagger}$ The entire period.

demonstrated that functional improvement does not depend on patient age at transplantation. Chacon et al. ${ }^{(26)}$ evaluated 7 IPF patients undergoing single lung transplantation. Pulmonary function tests were performed 6-12 months after lung transplantation, mean FVC and FEV having improved by $92 \%$ and $78 \%$, respectively. No such results were obtained at other centers.

Lanuza et al. ${ }^{(27)}$ evaluated lung function in 10 patients undergoing lung transplantation (bilateral lung transplantation in 2 and single lung transplantation in 8). Reasons for lung transplantation included pulmonary fibrosis, in 1 patient, cystic fibrosis, in 4, and COPD, in 5. In the third month after transplantation, mean FVC and $\mathrm{FEV}_{1}$ had increased by $58 \%$ and $55 \%$, respectively, from baseline.

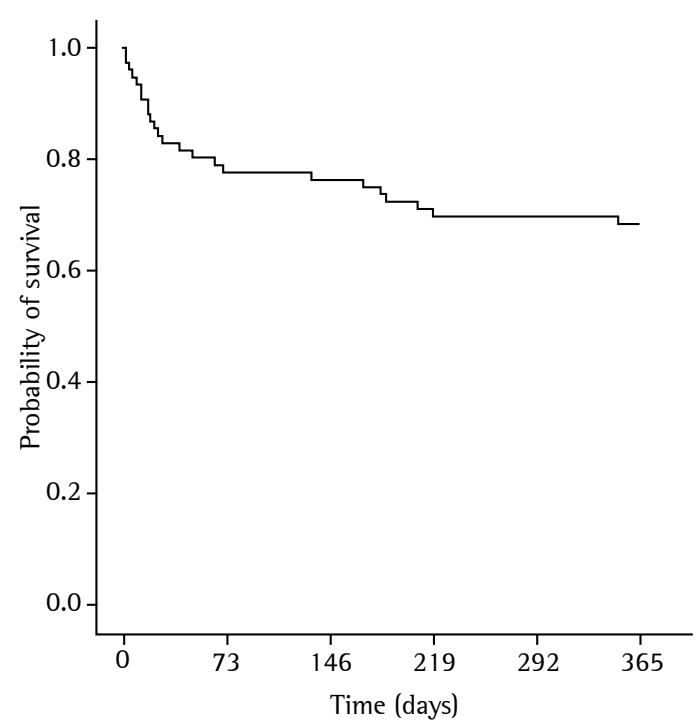

Figure 2 - One-year survival curve for patients with idiopathic pulmonary fibrosis undergoing single lung transplantation $(\mathrm{N}=79)$.

Pêgo-Fernandes et al. ${ }^{(28)}$ observed a similar functional improvement at the end of the first year after transplantation, the increase in FVC being greater in the patients who had undergone bilateral lung transplantation than in those who had undergone single lung transplantation.

Given that this was a retrospective cohort study, design-related limitations should be taken into consideration. Given that measurements of lung volumes and pulmonary diffusing capacity were not always available or reproducible, we chose to evaluate only FVC and FEV (as assessed by spirometry). All lung transplant procedures were performed by the same surgical team at the same location, the same technique being 
used in all procedures. One of the limitations of the study was that only single lung transplant procedures were performed and only single lung transplant recipients were analyzed; in several international centers, bilateral lung transplantation is preferred, being more beneficial in terms of patient survival. ${ }^{(12)}$ The decision to perform single lung transplantation (rather than bilateral lung transplantation) is mainly due to the scarcity of donor lungs, which are not enough to meet the demand of patients waiting for lung transplantation. Therefore, when both donor lungs are viable, two different patients can undergo transplantation at the same time, thus reducing waiting time for lung transplantation (which is crucial for the survival of patients with advanced lung disease). All pharmacological treatments available for IPF at the time of the study were in accordance with international guidelines and were found to have no impact on functional outcome measures. As was the case with the surgical procedures, all pulmonary function tests were performed by the same team (of technicians) using the same equipment, thus contributing to a homogeneous analysis.

On the basis of the data of the present study, we conclude that IPF patients undergoing single lung transplantation have a significant improvement in lung function during the first year of follow-up. These data are significant because IPF inexorably progresses to loss of lung function, being an important marker of poor prognosis. The impact that new drugs such as pirfenidone ${ }^{(29)}$ and nintedanib ${ }^{(30)}$ have on the survival of patients with IPF has yet to be examined. Lung transplantation is currently considered the only treatment modality that can have a significant impact on disease progression and should always be discussed in cases in which the risk of respiratory failure and death is high. However, further studies are needed in order to determine exactly how lung function improves after lung transplantation in patients with IPF.

\section{References}

1. Raghu G, Collard HR, Egan JJ, Martinez FJ, Behr J, Brown KK, et al. An official ATS/ERS/JRS/ALAT statement: idiopathic pulmonary fibrosis: evidence-based guidelines for diagnosis and management. Am J Respir Crit Care Med. 2011;183(6):788-824. http://dx.doi.org/10.1164/ rccm.2009-040GL

2. Sociedade Brasileira de Pneumologia e Tisiologia. Diretrizes de Doenças Pulmonares Intersticiais da
Sociedade Brasileira de Pneumologia e Tisiologia. J Bras Pneumol. 2012;38(Suppl 2):S1-S133.

3. Coletta EN, Pereira CA, Ferreira RG, Rubin AS, Villela LS, Malheiros T, et al. Achados histológicos e sobrevida na fibrose pulmonar idiopática. J Pneumol. 2003;29(6):371-8. http://dx.doi.org/10.1590/S0102-35862003000600009

4. Thabut G, Mal H, Castier Y, Groussard O, Brugière O, Marrash-Chahla R, et al. Survival benefit of lung transplantation for patients with idiopathic pulmonary fibrosis. J Thorac Cardiovasc Surg. 2003;126(2):469-75. http://dx.doi.org/10.1016/S0022-5223(03)00600-7

5. Bjoraker JA, Ryu JH, Edwin MK, Myers JL, Tazelaar HD, Schroeder DR, et al. Prognostic significance of histopathologic subsets in idiopathic pulmonary fibrosis. Am J Respir Crit Care Med. 1998;157(1):199-203. http:// dx.doi.org/10.1164/ajrccm.157.1.9704130

6. Mogulkoc N, Brutsche MH, Bishop PW, Greaves SM, Horrocks AW, Egan JJ, et al. Pulmonary function in idiopathic pulmonary fibrosis and referral for lung transplantation. Am J Respir Crit Care Med. 2001;164(1):103-8. http://dx.doi.org/10.1164/ ajrccm.164.1.2007077

7. Idiopathic Pulmonary Fibrosis Clinical Research Network, Raghu G, Anstrom KJ, King TE Jr, Lasky JA, Martinez FJ. Prednisone, azathioprine, and $\mathrm{N}$-acetylcysteine for pulmonary fibrosis. N Engl J Med. 2012;366(21):196877. http://dx.doi.org/10.1056/NEJMoa1113354

8. Elicker BM, Golden JA, Ordovas KG, Leard L, Golden TR, Hays SR. Progression of native lung fibrosis in lung transplant recipients with idiopathic pulmonary fibrosis. Respir Med. 2010;104(3):426-33. http://dx.doi. org/10.1016/j.rmed.2009.10.019

9. George TJ, Arnaoutakis GJ, Shah AS. Lung transplant in idiopathic pulmonary fibrosis. Arch Surg. 2011;146(10):1204-9. http://dx.doi.org/10.1001/ archsurg. 2011.239

10. Unilateral lung transplantation for pulmonary fibrosis. Toronto Lung Transplant Group. N Engl J Med. 1986;314(18):1140-5. http://dx.doi.org/10.1056/ NEJM198605013141802

11. Meyer DM, Edwards LB, Torres F, Jessen ME, Novick RJ. Impact of recipient age and procedure type on survival after lung transplantation for pulmonary fibrosis. Ann Thorac Surg. 2005;79(3):950-7; discussion 957-8. http:// dx.doi.org/10.1016/j.athoracsur.2004.08.076

12. Christie JD, Edwards LB, Aurora P, Dobbels F, Kirk R, Rahmel AO, et al. The Registry of the International Society for Heart and Lung Transplantation: Twenty-sixth Official Adult Lung and Heart-Lung Transplantation Report2009. J Heart Lung Transplant. 2009;28(10):1031-49. http://dx.doi.org/10.1016/j.healun.2009.08.004

13. Yusen RD, Shearon TH, Qian Y, Kotloff R, Barr ML, Sweet $\mathrm{S}$, et al. Lung transplantation in the United States, 1999-2008. Am J Transplant. 2010;10(4 Pt 2):1047-68.

14. Sociedade Brasileira de Pneumologia e Tisiologia. Diretrizes para testes de função pulmonar. J Pneumol. 2002; 28(Suppl 3):S1-S238.

15. Montoya A, Mawulawde K, Houck J, Sullivan H, Lonchyna V, Blakeman B, et al. Survival and functional outcome after single and bilateral lung transplantation. Loyola Lung Transplant Team. Surgery. 1994;116(4):712-8.

16. Machuca TN, Schio SM, Camargo SM, Lobato V, Costa CD, Felicetti JC, et al. Prognostic factors in lung transplantation: the Santa Casa de Porto Alegre experience. 
Transplantation. 2011;91(11):1297-1303. http://dx.doi. org/10.1097/TP.0b013e31821ab8e5

17. Kotloff RM, Thabut G. Lung Transplantation. Am J Respir Crit Care Med. 2011;184(2):159-71. http://dx.doi. org/10.1164/rccm.201101-0134Cl

18. Flaherty KR, Mumford JA, Murray S, Kazerooni EA, Gross BH, Colby TV, et al. Prognostic implications of physiologic and radiographic changes in idiopathic interstitial pneumonia. Am J Respir Crit Care Med. 2003;168(5):543-8. http://dx.doi.org/10.1164/rccm.200209-11120C

19. American Thoracic Society; European Respiratory Society. American Thoracic Society/European Respiratory Society International Multidisciplinary Consensus Classification of the ldiopathic Interstitial Pneumonias. This joint statement of the American Thoracic Society (ATS), and the European Respiratory Society (ERS) was adopted by the ATS board of directors, June 2001 and by the ERS Executive Committee, June 2001. Am J Respir Crit Care Med. 2002;165(2):277-304. http://dx.doi.org/10.1164/ ajrccm.165.2.ats01

20. Pellegrino R, Viegi G, Brusasco V, Crapo RO, Burgos F, Casaburi R, et al. Interpretative strategies for lung function tests. Eur Respir J. 2005;26(5):948-68. http:// dx.doi.org/10.1183/09031936.05.00035205

21. Pereira, CA, Sato T, Rodrigues SC. New reference values for forced spirometry in white adults in Brazil. J Bras Pneumol. 2007;33(4):397-406. http://dx.doi.org/10.1590/ S1806-37132007000400008

22. Hayden AM, Robert RC, Kriett JM, Smith CM, Nicholson K, Jamieson SW. Primary diagnosis predicts prognosis of lung transplant candidates. Transplantation. 1993;55(5):104850. http://dx.doi.org/10.1097/00007890-199305000-00019

23. Algar FJ, Espinosa D, Moreno P, Illana J, Cerezo F, Alvarez A, et al. Results of lung transplantation in idiopathic pulmonary fibrosis patients. Transplant Proc. 2010;42(8):3211-3. http://dx.doi.org/10.1016/j. transproceed.2010.05.046
24. Bartels MN, Armstrong HF, Gerardo RE, Layton AM, Emmert-Aronson BO, Sonett JR, et al. Evaluation of pulmonary function and exercise performance by cardiopulmonary exercise testing before and after lung transplantation. Chest. 2011;140(6):1604-11. http:// dx.doi.org/10.1378/chest.10-2721

25. Tomaszek SC, Fibla JJ, Dierkhising RA, Scott JP, Shen KR, Wigle DA, et al. Outcome of lung transplantation in elderly recipients. Eur J Cardiothorac Surg. 2011;39(5):726-31. http://dx.doi.org/10.1016/j.ejcts.2010.08.034

26. Chacon RA, Corris PA, Dark JH, Gibson GJ. Comparison of the functional results of single lung transplantation for pulmonary fibrosis and chronic airway obstruction. Thorax. 1998;53(1):43-9. http://dx.doi.org/10.1136/ thx.53.1.43

27. Lanuza DM, Lefaiver C, Mc Cabe M, Farcas GA, Garrity E Jr. Prospective study of functional status and quality of life before and after lung transplantation. Chest. 2000;118(1):115-22. http://dx.doi.org/10.1378/ chest.118.1.115

28. Pêgo-Fernandes PM, Abrão FC, Fernandes FL, Caramori ML, Samano MN, Jatene FB. Spirometric assessment of lung transplant patients: one year follow-up. Clinics (Sao Paulo). 2009;64(6):519-25. http://dx.doi.org/10.1590/ S1807-59322009000600006

29. King TE Jr., Bradford WZ, Castro-Bernardini S, Fagan EA, Glaspole 1, Glassberg MK, et al. A phase 3 trial of pirfenidone in patients with idiopathic pulmonary fibrosis. N Engl J Med. 2014;370(22):2083-92. http:// dx.doi.org/10.1056/NEJMoa1402582

30. Richeldi L, du Bois RM, Raghu G, Azuma A, Brown KK, Costabel U, et al. Efficacy and safety of nintedanib in idiopathic pulmonary fibrosis. $\mathrm{N}$ Engl J Med. 2014;370(22):2071-82. http://dx.doi.org/10.1056/ NEJMoa 1402584 